\title{
Preferensi konsumen terhadap konsumsi "ragey" di Kota Manado
}

\author{
S. G. Dama, S. P. Pangemanan*, J. K.J. Kalangi, A. Makalew \\ Fakultas Peternakan Universitas Sam Ratulangi Manado 95119 \\ *Korespondensi (corresponding author): stevypangemanan@unsrat.ac.id
}

\begin{abstract}
ABSTRAK
Penelitian ini bertujuan Untuk mengetahui preferensi Konsumen dan atribut yang menjadi pertimbangan konsumen terhadap ragey di Kota Manado.Penelitian ini dilaksanakan di Kota Manado Propinsi Sulawesi Utara.Penentuan lokasi dilakukan secara sengaja (Purposive sampling) pada tiga rumah makan yang menjual ragey yaitu rumah makan ragey Tanta Olla, rumah makan ragey Roy dan rumah makan ragey 21 Telling pada tanggal 08 Juli sampai tanggal 08 Agustus 2019.Metode penelitian yaitu metode survey dan wawancara menggunakan kuisioner yang telah disediakan.Penentuan sampel dilakukan secara accidental sampling dengan 100 sampel.Jenis data adalah data primer dan data sekunder serta analisis deskriptif dan analisis Konjoin. Hasil analisis konjoin memberikan hasil korelasi yang signifikan $(\mathrm{P}<0,05)$ antara preferensi konsumen denga atribut ragey. Ragey yang menjadi preferensi konsumen di rumah makan yang ada di Kota Manado adalah atribut harga dengan nilai 0,530, atribut ukuran yang kecil dengan nilai 0.410 dan atribut proporsi pada daging dengan nilai 0,700. Atribut yang menjadi pertimbangan konsumen dalam membeli ragey secara berurut yaitu proporsi $34,808 \%$, ukuran 33,896\% dan harga 31,296\%.
\end{abstract}

Kata kunci : Preferensi konsumen, atribut ragey, analisis konjoin.

\begin{abstract}
ABTRACT
CONSUMER PREFERENCES TOWARDS RAGEY CONSUMPTION IN MANADO CITY.This study aims to determine consumer preferences and attributes that are considered consumers of ragey in Manado City. This research was conducted in Manado City, North Sulawesi Province. The location determination was carried out deliberately (purposive sampling) at three restaurants selling ragey, namely the ragey restaurant Tanta Olla, the ragey Roy restaurant and the ragey 21 Telling restaurant from 08 July to 08 August 2019. The research method is survey and interview methods using a questionnaire that has been provided. Samples were determined by accidental sampling with 100 samples. Types of data are primary data and secondary data as well as descriptive analysis and conjoint analysis. The results showed that ragey atributs such as price with a value of 0.530 , size with a value of 0.410 and proportion of meat with a value of 0.700 had significant correlation $(\mathrm{P}<0,05)$ with consumers preferences. Attributes that are considered by consumers in buying ragey sequentially, namely the proportion of $34.808 \%$, size $33.896 \%$ and price of $31.296 \%$.
\end{abstract}

Keywords:consumer preference, ragey attribute, conjoint analysis. 


\section{PENDAHULUAN}

sub-sektor peternakan merupakan bagian dari sektor pertanian. Sub-sektor peternakan memiliki nilai strategis dalam memenuhi kebutuhan pangan yang memiliki nilai gizi untuk masyarakat.Salah satu bahan pangan hewani yang memiliki nilai gizi yang tinggi dan dapat diolah menjadi berbagai jenis olahan, yang lezat dan bergizi adalah daging.Daging mengandung protein, air, lemak, karbohidrat, vitamin dan mineral.Bagi masyarakat tertentu di Indonesia, daging babi sering dikonsumsi untuk memenuhi kebutuhan protein (Tana et al., 2015).

Konsumen akan memilih produk yang diinginkan sehingga produsen harus mengetahui apa yang menjadi selera konsumen. Selera konsumen adalah tindakan yang terlibat secara langsung dalam memperoleh, mengkonsumsi dan membuang suatu produk atau jasa, termasuk proses keputusan yang mengikuti tindakan tersebut (Syafriadi, 2016) Meningkatkan selera seseorang terhadap suatu barang tertentu pada umumnya berakibat naiknya jumlah permintaan terhadap barang tersebut begitu pula sebaliknya menurunnya selera konsumen terhadap suatu barang tertentu pada umumnya berakibat berkurangnya jumlah permintaan terhadap barang tersebut.Menurut Wijayanti (2011) mengatakan, Preferensi konsumen adalah pemilihan suka atau tidak sukanya seseorang terhadap produk (barang atau jasa) yang dikonsumsi dengan mempertimbangkan beberapa hal seperti harga yang dapat terjangkau, memiliki nila guna bagi masyarakat dan sebagainya, yang dapat memenuhi kepuasan dari konsumen. Preferensi Pelanggan Dalam literatur psikologi, preferensi dapat dianggap sebagai sikap individu terhadap satu set objek, biasanya tercermin dalam proses pengambilan keputusan eksplisit. sebagian besar masyarakat yang ada di Kota Manado mengkonsumsi daging babi dibandingkan daging lainnya sebagai salah satu kebutuhan gizi dikarenakan penduduk di Kota Manado kebanyakan beragama nasrani. Jenis-jenis makanan khas Minahasa seperti babi putar, tinoransak, babi tore, babi leilem, sate babi dan ragey (Kandou, 2009) Salah satu makanan khas yang diminati oleh masyarakat di Kota Manado adalah ragey. Ragey pertama kali dikenal dari daerah Minahasa Bagian Tengah Desa Kawangkoan Utara.Nama ragey untuk makanan tersebut, diambil dari kebiasaan penyebutan masyarakat Minahasa."Biasanya kalau ada yang potong babi, mereka potong beberapa bagian dan bilang rageyen atau dalam bahasa Tountemboan artinya 'bakar akang' (tolong dibakar)".'Ragey dijual dalam kemasan paket (nasi, sayur dan minuman) atau dijual pertusuknya. Penampilan ragey dalam bentuk ukuran, proporsi dan harga yang berbeda-beda sesuai yang disajikan oleh rumah makan, yang akan dibuat dalam bentuk atribut agar konsumen dapat memilih ragey yang diinginkan. Atribut produk pada dasarnya merupakan keunggulan dan keunikan yang dimiliki oleh produk dan merupakan pembeda antara produk sejenis yang ditawarkan oleh perushaan dengan perusahaan lainnya (sudrajad et al., 2015).

Konsumen akan mendasarkan harapannya kepada informasi yang mereka terima tentang produk dan memperhatikan serta mempertimbangkan ciri-ciri fisik (atribut) produk sebelum membeli. Jika kenyataan yang mereka dapat ternyata berbeda dengan yang diharapkan maka mereka tidak puas. Namun, apabila produk tersebut memenuhi harapan, mereka akan merasa puas. Dalam hal ini atribut produk merupakan hal yang sangat penting untuk dipertimbangkan oleh konsumen sebelum membeli sebuah produk (Simarmata et al., 2019).Begitu juga dalam membeli produk ragey, beberapa atribut yang menjadi 
pertimbangan konsumen yaitu harga, ukuran dan proporsi.

Produk ragey Di Kota Manado perlu diteliti lebih lanjut dalam hal pengolahan dan perkembangannya untuk menjawab konsumen dalam memilih rasa atau ciri khas dari ragey tersebut, apakah sudah berubah seperti aslinya. Dalam penelitian ini juga akan menjawab preferensi konsumen akan minat ragey yang sesuai dengan keinginan konsumen. Tujuan dari penelitian ini adalah Untuk mengetahui preferensi Konsumen dan atribut-atribut "ragey" yang menjadi pertimbangan konsumen di Kota Manado.

\section{METODE PENELITIAN}

\section{Tempat dan waktu penelitian}

Penelitian ini dilakukan di Kota Manado Propinsi Sulawetsi Utara. Penentuan lokasi (rumah makan) dilakukan secara sengaja (Purposive sampling) pada tiga rumah makan yang menjual ragey yang berada di kota Manado yaitu Rumah Makan "Ragey" Tanta Olla, Rumah maka "Ragey" Roy dan Rumah Makan "Ragey" 21 Telling. Pemilihan lokasi ini berdasarkan pertimbangan bahwa rumah makan tersebut menjual produk ragey sudah lebih dari 5 tahun.

Waktu penelitian dilakukan selama satu (1) bulan yaitu tanggal 08 Juli sampai tanggal 08 Agustus 2019.

\section{Jenis data dan sumber data}

Jenis data yang akan digunakan dalam penelitian ini adalah jenis kualitatif dan kuantitatif. Data yang digunakan dalam penelitian ini adalah data primer dan data sekunder. Data primer diperoleh dengan mengunakan teknik wawancara langsung secara lisan, sepihak dan dengan arah tujuan yang telah ditentukan kepada pemilik (owner) usaha rumah makan ragey dengan menggunakan daftar pertanyaan (kuesioner) sebagai alat bantu dalam pengumpulan data.
Data sekunder dapat di peroleh dari instansiinstansi yang berkaitan dengan penelitian ini seperti kantor dinas pertanian/peternakan dan kantor kecamatan.

\section{Penentuan sampel}

Metode yang digunakan pada pengambilan sampel dalam penelitian ini dengan cara accidental sampling yaitu tidak secara sengaja atau secara kebetulan. Sampel penelitian ditentukan dengan cara menaksir parameter proporsi (Kurniawan, 2014) karena dalam penelitian ini jumlah populasinya tidak diketahui, jumlah sampel yang diambil dalam penelitian ini sebanyak 100 responden. Wawancara dan pengambilan data melalui kuisioner yang telah dijalankan pada rumah makan Tanta Olla, rumah makan ragey Roy dan rumah makan ragey 21 Teling di Kota Manado.

\section{Analisis data}

\section{Analisis deskriptif}

Menggambarkan rumah makan "ragey" yang ada di Kota Manado dengan menggunakan analisis deskripstif.Menurut Muhamad dan Djaali (2003), analisis deskriptif adalah jenis analisis data yang dimaksudkan untuk mengungkapkan keadaan atau karakteristik data sampel untuk masing-masing variable penelitian secara tunggal.Analisis deskriptif dilakukan dengan menggunakan teknik-teknik statistik deskriptif yang meliputi tabel frekuensi, grafik, ukuran pemusatan (gejala pusat) dan ukuran penyebaran.

Berdasarkan pengertian diatas dapat disimpulkan bahwa analisis penelitian deskriptif merupakan suatu analisis yang digunakan untuk mendeskripsikan responden di rumah makan "ragey" yang ada di Kota Manado dalam bentuk rataan tabulasi, bagan dan gambar dengan menggunakan program Microsoft excel. 


\section{Analisis konjoin}

Menurut Purba et al., (2013) menyatakan bahwa Analisis konjoin merupakan salah satu teknik analisis multivariat yang digunakan untuk mengetahui preferensi konsumen terhadap suatu produk baik berupa barang atau jasa. Teknik analisis konjoin penting karena banyak faktor yang mempengaruhi penilaian konsumen dalam menentukan pilihan suatu produk analisis konjoin juga tepat dan baik untuk menentukan strategi pemasaran.Analisis konjoin bertujuan untuk mengetahui bagaimana persepsi seseorang terhadap suatu objek yang terdiri dari satu atau lebih bagian (Noegroho 2013).Hasil utama dari analisis konjoin adalah suatu bentuk (desain) produk barang atau jasa, atau objek tertentu yang diinginkan oleh sebagian besar responden (Santoso, 2010).Model dasar conjoint analysis dapat dirumuskan sebagai berikut :

Keterangan :

$$
U(x)=\sum_{i-1}^{m} \sum_{j=1}^{k_{\mathrm{i}}} a_{\mathrm{i}} x_{\mathrm{i}}
$$

$\mathrm{U}(\mathrm{x})=$ seluruh utility dari suatu

alternatif (overall utility of an

alternative)

$\mathrm{a}_{\mathrm{i}} \quad=$ sumbangan utility yang terkait

dengan level ke- $j$

$\mathrm{k}_{\mathrm{i}} \quad=$ banyaknya level atribut $\mathrm{i}$

$\mathrm{m} \quad=$ banyaknya atribut $\mathrm{i} \quad=1,2, \ldots, \mathrm{m}$ (atribut ke-i)

$j \quad=1,2, \ldots$, ki (level ke-j)

$\mathrm{x}_{\mathrm{i}} \quad=1$; apabila level ke-j dari

atribut ke-I terjadi

dan $=0 ;$ apabila tidak terjadi

(Supandi, 2012).

Atribut yang telah ditentukan yaitu harga, ukuran dan proporsi sedangkan untuk taraf atributnya diperoleh dari rumah makan tanta olla, "ragey" roy dan "ragey" 21 telling. Hasil penentuan atribut dan taraf atribut yaitu 1). harga "ragey" terdiri dari 3 taraf atribut yaitu harga Rp. 5.000, Rp. 8.000 dan Rp. 8,500, 2). Ukuran "ragey" terdiri dari 3 taraf atribut yaitu ukuran besar, sedang dan kecil dan 3).Proporsi "ragey" terdiri dari 3 taraf atribut yaitu proporsi daging-daging, daging-lemak, dan lemaklemak.

Pembentukan stimuli adalah hasil kombinasi dari penentuan atribut dan taraf atribut.Maka stimuli yang didapat sebanyak $3 \times 3 \times 3=27$ stimuli.dengan jumlah 27 stimuli terbilang cukup banyak untuk diberikan kepada para responden. Maka stimuli tersebut dapat dikurangi dengan fractional factorial dengan konsep generate orthogonal design menggunakan spss 21 hanya dihasilkan 9 stimuli atau 9 kartu profil. Tabel 1 kartu profil dapat dilihat dibawah ini.

Tabel 1. Kartu Profil

\begin{tabular}{cccc}
\hline Kartu & Harga & Ukuran & Proporsi \\
\hline 1 & 8,500 & besar & Daging-daging \\
2 & 5,000 & sedang & Lemak-lemak \\
3 & 8,500 & kecil & Lemak-lemak \\
4 & 5,000 & besar & Daging-lemak \\
5 & 8,000 & besar & Lemak-lemak \\
6 & 8,500 & sedang & Daging-lemak \\
7 & 8,000 & sedang & Daging-daging \\
8 & 8,000 & kecil & Daging-lemak \\
9 & 5,000 & kecil & Daging-daging \\
\hline
\end{tabular}




\section{HASIL DAN PEMBAHASAN}

\section{Karakteristik rumah makan}

Tempat penelitian yang dilakukan pada 3 rumah makan, yaitu rumah makan Tanta Olla nama pemilik Nikolina Pelealu, umur 53 tahun, pendidikan terakhir SMA, lama usaha adalah 11 tahun, rumah makan Ragey Roy nama pemilik Roy Manangka, umur 50 tahun, pendidikan terakhir SMA, lama usaha 2 tahun (cabang dari Kota Tomohon yang sudah dikelola kurang lebih 10 tahun) dan rumah makan Ragey 21 Teling nama pemilik Devi Wurara, umur 43 tahun, pendidikan terakhir SMK, lama usaha 6 tahun dalam hal ini usia dari ketiga pemilik usaha rumah makan tersebut produktif memiliki pendidikan menengah atas yang sudah dapat mempengaruhi pola pikir serta usaha yang dikelola oleh ketiga rumah makan tersebut sudah lebih dari 5 tahun sehingga lama usaha akan berpengaruh pada perkembangan usaha. Tingkat pengalaman berwirausaha memiliki pengaruh yang signifikan terhadap pengembangan usaha untuk memiliki kemampuan dalam mengambil sebuah keputusan.Sehingga semakin lama usaha tersebut maka pengalaman dalam berwirausaha dapat memiliki kemampuan dalam bertahan dan mencari jalan keluar, serta mampu untuk menghadapi resiko (Wahyuni et al., 2015).

\section{Karakteristik responden}

Jumlah responden yang diambil dalam penelitian ini sebanyak 100. 40 orang laki-laki dan 60 orang perempuan Jenis kelamin adalah salah satu karakteristik responden yang perlu diketahui untuk melihat preferensi dari konsumen, karena jenis kelamin akan mempengaruhi seseorang dalam membeli makanan yang sesuai dengan kebutuhan dalam hal ini perempuan lebih senang berbelanja, dapat dilihat pada Tabel 2. Menurut Hermanianto dan
Andayani (2002) menjelaskan bahwa wanita umumnya cenderung lebih senang berebelanja, mudah terpengaruh oleh emosi dan menyukai jajan atau ngemil.Sehingga alasan ini yang menjadikan perempuan sebagai konsumen terbesar dalam hal berbelanja.

Umur dari responden 20-50 tahun, umur adalah salah satu karakteristik yang perlu diketahui untuk melihat preferensi dari konsumen karena umur dapat berpengaruh terhadap pemilihan suka atau tidaknya konsumen. Umur yang semakin dewasa akan mempengaruhi selera seseorang dalam memilih produk yang selektif, dapat dilihat pada Tabel 2. Menurut Aritonang (2015), menyatakan bahwa selera seseorang terhadap barang/jasa sangat berhubungan dengan umur, semakin dewasa umur seseorang maka keputusan untuk mengkonsumsi suatu barang semakin selektif.

pendidikan responden SMAPascasarjana pendidikan juga berpengaruh untuk pengetahuan dan informasi yang dapat diterima untuk mempertimbangkan produk hal ini dikarenakan pada tingkat pendidikan yang semakin tinggi responden akan lebih banyak pengetahuan dan pengalaman mengenai makanan yang sehat dan bergizi (Kalsum et al., 2013). Dapat dilihat pada Tabel 2.

Jenis pekerjaan responden pelajar/mahasiswa, PNS, Wiraswasta, pegawai swasta, Ibu rumah tangga dan lainnya pekerjaan sangat berpengaruh dalam menghasilkan suatu pendapatan sehingga responden yang memiliki pekerjaan lebih baik akan dapat berbelanja dengan sesuka hatinya. Dapat dilihat pada Tabel 2.

pendapatan responden berkisar $<1.500 .000->5.000 .000$ pendapatan juga berpengaruh dalam membeli produk karena semakin banyak pendapatan seemakin tinggi niat konsumen untuk berbelanja. Dapat dilihat pada Tabel 2 . 
Tabel 2. Karakteristik Responden

\begin{tabular}{|c|c|c|c|}
\hline No. & Keterangan & Jumlah Orang & Presentase $(\%)$ \\
\hline & Jenis Kelamin & & \\
\hline 1. & Laki-laki & 40 & 40 \\
\hline \multirow[t]{2}{*}{2.} & Perempuan & 60 & 60 \\
\hline & Umur (Tahun & & \\
\hline 1. & $20-30$ & 46 & 46 \\
\hline 2. & $31-40$ & 24 & 24 \\
\hline \multirow[t]{2}{*}{3.} & $41-50$ & 30 & 30 \\
\hline & Pendidikan Terakhir & & \\
\hline 1. & Tidak Sekolah & 0 & 0 \\
\hline 2. & SD & 0 & 0 \\
\hline 3. & SMP & 0 & 0 \\
\hline 4. & SMA & 34 & 34 \\
\hline 5. & Diploma & 11 & 11 \\
\hline 6. & Sarjana & 48 & 48 \\
\hline \multirow{2}{*}{7.} & Pascasarjana & 7 & 7 \\
\hline & Jenis Pekerjaan & & \\
\hline 1. & Pelajar/Mahasiswa & 15 & 15 \\
\hline 2. & PNS & 44 & 44 \\
\hline 3. & Wiraswasta & 14 & 14 \\
\hline 4. & Pegawai Swasta & 13 & 13 \\
\hline 5. & Ibu Rumah Tangga (IRT) & 11 & 11 \\
\hline 6. & Pensiunan & 0 & 0 \\
\hline \multirow[t]{2}{*}{7.} & Lainnya & 3 & 3 \\
\hline & Pendapatan (Rp) & & \\
\hline 1. & $<1,500,000$ & 3 & 3 \\
\hline 2. & $1,500,001-2,500,000$ & 8 & 8 \\
\hline 3. & $2,500,001-3,500,000$ & 23 & 23 \\
\hline 4. & $3,500,001-4,500,000$ & 36 & 36 \\
\hline 5. & $4,500,001-5,000,000$ & 22 & 22 \\
\hline 6. & $>5,000,000$ & 8 & 8 \\
\hline
\end{tabular}

\section{Analisis Preferensi Konsumen}

Preferensi responden terhadap "ragey" adalah pilihan suka atau tidak sukanya seseorang terhadap produk "ragey" yang dikonsumsi.Pilihan tersebut berbedabeda terhadap konsumen yang satu dengan konsumen yang lainnya.Untuk mengukur preferensi konsumen terhadap "ragey" dirumah makan menggunakan analisis konjoin. Pada penelitian ini menggunakan 3 atribut yaitu harga, ukuran dan proporsi. Masing-masing atribut tersebut memiliki sub/taraf atribut. Atribut harga terdiri dari taraf Rp. 5.000, Rp. 8.000 dan Rp. 8.500, atribut ukuran terdiri dari taraf kecil, sedang dan besar kemudian atribut proporsi terdiri dari taraf daging, daging-lemak dan lemak.

Berdasarkan hasil analisis diperoleh nilai signifikan pada pearson's $\mathrm{R}$ sebesar 0.000 dan kendall's tau sebesar 0.002 hasil ini menyimpulkan bahwa penelitian ini dianggap valid karena angka pada person dan Kendal memberikan hasil korelasi dengan tingkat signifikan lebih kecil dari taraf nyata $=0,05$. Dapat dilihat pada Tabel 3. 
Tabel 3. Nilai Signifikan Dari Atribut-Atribut Yang Digunakan

\begin{tabular}{ccc}
\hline & Value & Sig. \\
\hline Pearson's R & .986 & .000 \\
Kendall's tau & .778 & .002 \\
\hline
\end{tabular}

Correlations between observed and estimated preferences

Hasil penelitian ini menunjukkan bahwa adanya hubungan yang sginifikan atau memiliki hubungan yang positif dan sangat erat antara preferensi konsumen dalam membeli "ragey" dengan atribut-atribut yang telah digunakan dalam penelitian ini.Pada Penelitian tentang "Analisis Preferensi Konsumen Terhadap Keputusan Pembelian Abon Ikan Tuna" pada atribut halal, kemasan, ukuran, dan rasa memperoleh nilai korelasi yang memiliki hubungan antara kombinasi atribut dengan preferensi konsumen juga nilai signifikan sebesar 0.000 yang lebih kecil dari taraf signifikan yang digunakan sebesar 0.05 (Putri, 2017).

Dari hasil pengolahan spss 21 nilai utility dari masing-masing level atribut memiliki dua tanda. Tanda nilai positif yang diperoleh mempunyai arti bahwa jika tejadi perubahan pada suatu level atribut yang ditawarkan kepada konsumen maka hasil tersebut dapat meningkatkan utilitas sebesar nilai positif yang diperoleh sebaliknya jika tanda nilai negatif berarti jika tidak memasukkan salah satu dari level atribut yang ditawarkan maka dapat menurunkan utilitas sebesar nilai negative yang diperoleh (Kalsum et al., 2013).

Pada Tabel 4 dapat dilihat bahwa atribut harga dari sub/taraf atribut yang banyak disukai responden adalah harga Rp. 8.000 dengan nilai sebesar 0.530 lebih besar dibandingkan dengan nilai taraf atribut harga lainnya. Hal ini menunjukan bahwa konsumen menyukai harga ragey yang menengah atau harga yang tidak terlalu mahal. Hasil ini didukung oleh penelitian Cahyanti dan Mukhamad (2016) mengenai analisis preferensi konsumen terhadap atribut yogurt drink (studi kasus kota bogor jawa barat) menjelaskan bahwa konsumen lebih menyukai harga yogurt drink yang menengah atau harga yang tidak terlalu mahal dan tidak terlalu murah dengan harapan produk tersebut dapat memenuhi kebutuhan dan keinginan konsumen dengan produk yang memiliki mutu baik.

Pada atribut ukuran, responden lebih banyak memilih "ragey" yang berukuran kecil dengan nilai sebesar 0.410 lebih besar dibandingkan dengan taraf atribut lainnya. Dari nilai yang diperoleh menunjukan bahwa responden lebih banyak menyukai ukuran yang kecil, meskipun sebenarnya ukuran "ragey" adalah besar tetapi "ragey" yang dijual sekarang juga ada yang berukuran kecil sehingga ketika kuesioner yang telah diberikan kepada responden menunjukan bahwa responden lebih menyukai "ragey" yang berukuran kecil. Pada penelitian tentang "studi perilaku konsumen dan identifikasi parameter bakso sapi berdasarkan preferensi konsumen di wilayah DKI Jakarta" konsumen sebagian besar lebih menyukai bakso yang berukuran sedang dibandingkan dengan bakso yang berukuran besar karena semakin besar ukuran bakso maka akan semakin sedikit butir atau jumlah bakso yang didapatkan konsumen, sehingga konsumen lebih memilih ukuran yang sedang karena menginginkan jumlah bakso yang lebih banyak dan harga yang dapat dijangkau (Hermanianto dan Andayani, 2002). 
Tabel 4.Nilai Utiliti Masing-masing Atribut dan Level Atribut Berdasarkan Hasil Analisis Konjoin

\begin{tabular}{llcc}
\hline \multirow{3}{*}{ harga } & & Utility Estimate & Std. Error \\
\hline \multirow{6}{*}{ ukuran } & Rp. 5,000 & -.220 & .161 \\
& Rp. 8,000 & .530 & .161 \\
& Rp. 8,500 & -.310 & .161 \\
& Kecil & .410 & .161 \\
\multirow{2}{*}{ proporsi } & Sedang & .287 & .161 \\
& Besar & -.697 & .161 \\
(constant) & Daging-daging & .700 & .161 \\
& Daging-lemak & .293 & .161 \\
& Lemak-lemak & -.993 & .161 \\
\hline
\end{tabular}

Begitu juga dengan "ragey" konsumen menginginkan ukuran yang kecil karena harga yang dapat dijangkau dan jumlah dalam pertusuk yang lebih banyak dengan nilai sebesar 0.700. Berdasarkan nilai tersebut konsumen yang membeli ragey paling menyukai proporsi daging. berdasarkan kuesioner yang diberikan kepada responden rata-rata berumur 25 tahun keatas, diumur 25 tahun keatas lebih menjaga kesehatan sehingga akan berhatihati dalam mengkonsumsi atau memilih makanan yang dapat menimbulkan penyakit. Sebagian responden tidak menyukai lemak karena lemak dapat menimbulkan penyakit hasil ini didukung oleh penelitian kandou (2009) mengenai makanan etnik minahasa dan kejadian penyakit jantung koroner dimana makanan minahasa yang sebagian besar berasal dari lemak hewani (babi) Jenis makanan etnik minahasa yang termasuk dalam kelompok makanan tinggi asam lemak jenuh salah satunya adalah daging babi yang dapat menyebabkan penyakit jantung koroner.

Pada Tabel 5 dihasilkan nilai atribut dari tingkat yang tertinggi hingga terendah. Berdasarkan nilai tingkat kepentingan atribut, pada urutan pertama atribut proporsi yang paling berpengaruh dengan nilai sebesar $34.808 \%$ yang artinya bahwa konsumen lebih mengutamakan atribut proporsi dalam membeli ragey dibandingkan dengan atribut lainnya. Menurut Atmoko dan Nang (2016) mengkonsumsi dagingberlebihan dapat menyebabkan penyakit seperti hipertensi, serangan jantung, diabetes, obesitas dan gangguan kesehatan lainnya, sehingga konsumen lebih memperhatikan proporsi dalam membeli daging.

Pertimbangan kedua yang yang dipilih konsumen dalam membeli "ragey" adalah atribut ukuran dengan nilai sebesar $33.896 \%$. Berdasarkan nilai utility uji konjoin taraf atribut ukuran ragey yang dipilih konsumen yang paling banyak adalah berukuran kecil sedangkan pada penelitian tentang "studi perilaku konsumen dan identifikasi parameter bakso sapi berdasarkan preferensi konsumen di wilayah DKI Jakarta" pada atribut rasa, aroma, tekstur, warna dan ukuran yang menjadi pertimbangan konsumen paling terakhir adalah ukuran (Hermanianto dan Andayani, 2002). Kemudian yang menjadi pertimbangan terakhir dari konsumen dalam membeli "ragey" adalah atribut harga dengan nilai kepentingan sebesar $31.296 \%$. Hasil penelitian ini sejalan dengan Wantasen et al. (2019) dan Pamungkas et al. (2014) bahwa faktor harga bukan menjadi prioritas konsumen dalam memebeli daging sapi dibandingkan faktor tekstur dan rasa daging. 
Tabel 5. Tingkat Kepentingan Atribut

\begin{tabular}{cc}
\hline Atribut & Tingkat Kepentingan Atribut \\
\hline Harga & 31.296 \\
Ukuran & 33.896 \\
Proporsi & 34.808 \\
\hline
\end{tabular}

Hal ini dikarenakan konsumen lebih menginginkan kualitas yang lebih baik. Sehingga dalam penelitian ini harga juga menjadi pertimbangan yang terakhir dalam memilih "ragey", karena konsumen melihat masih ada pilihan lain yang lebih penting. Dari hasil kuesioner yang dijalankan responden lebih memperhatikan proporsi yang diberikan untuk menjaga kesehatan.

\section{KESIMPULAN}

Hasil penelitian "Ragey" yang menjadi preferensi konsumen di rumah makan yang ada Di Kota Manado Sulawesi Utara berdasarkan hasil analisis uji konjoin pada atribut harga yaitu Rp. 8.000, ukuran kecil, serta proporsi daging dan atribut-atribut yang menjadi pertimbangan konsumen dalam membeli "ragey" secara berurutan yaitu proporsi, ukuran dan harga.

\section{DAFTAR PUSTAKA}

Aritonang, S. N. 2015. Perilaku konsumen rumah tangga dalam memilih daging sapi di Kota Padang. Jurnal Ilmu Ternak. 15(2):1-7.

Atmoko, W. B. dan A. B. Nang. 2016. Sustainability consumtion: perubahan periliku mengkonsumsi daging. Jurnal Ekonomi Dan Bisnis. 19(2):249-262.

Cahyanti, T. dan N. Mukhamad.2016. Analisis preferensi konsumen terhadap atribut yogurt drink (Studi Kasus Kota Bogor Jawa Barat). Jurnal Aplikasi Manajemen. 14(1):176-183.
Hermanianto J. dan R. Y. Andayani.2002. Studi perilaku konsumen dan identifikasi parameter bakso sapi berdasarkan preferensi konsumen di wilayah DKI Jakarta. Jurnal Teknologi dan Industri Pangan. 13(1):1-10.

Kalsum, U., F. Elys dan R. D. A. N. Taufik. 2013. Preferensi konsumen dalam membeli rengginang lorjuk di Kecamatan Kamal Bangkalan. Jurnal Sosial Ekonomi Dan Kebijakan Pertanian. 2(2):163-189.

Kandou, G. D. 2009. Makanan etnik Minahasa dan kejadian penyakit jantung koroner. Jurnal Kesehatan Masyarakat Nasional. 4(1):42-48.

Kurniawan, A. 2014. Metode Riset Untuk Ekonomi Dan Bisnis. Teori, Konsep Dan Praktik Penelitian Bisnis, Bandung.

Muhammad, F. dan H. Djali.2003. Metodologi Penelitian Sosial. Jakarta.

Noegroho, C. A. 2013. Penerapan Analisis Konjoin Dalam Menentukan Persepsi Mahasiswa Matematika Terhadap Dosen. Skripsi. Program Studi Matematika. Fakultas Matematika Dan Ilmu Pengetahuan Alam. Universitas Pakuan. Bogor.

Pamungkas M.C., B. D. Probowati dan I. Maflahah. 2014. Pengukuran preferensi konsumen bakso. Agrointek. 8(1):32-39.

Purba, R. D., D. Open dan S. Pasukat. 2013. Analisis preferensi mahasiswa FMIPA USU terhadap produk handphone dengan menggunakan analisis konjoin. Jurnal Saintia Matematika. 1(2):187197. 
Putri P. 2017. Analisis preferensi konsumen Terhadap Keputusan Pembelian Abon Ikan Tuna. Thesis. Sekolah Pascasarjana. Universitas Hasanuddin Makasar.

Santoso, S. 2010. Statistik Multivariat Dengan Spss. Jakarta.

Simarmata L., R. E. M. F. Osak., E. K. M. Endoh dan F. N. S. Oroh. Analisis preferensi konsumen dalam membeli daging broiler di pasar tradisional Kota Manado (Studi Kasus'Pasar Pinasungkulan Karombasan"). Jurnal Zootec. 39(2):194-202.

Sudrajad, A. B. dan R. A. Dwi. 2015. Pengaruh atribut produk terhadap keputusan konsumen dalam pembelian produk abon jamur tiram di perusahaan ailanifood Kota Malang Jawa Timur. Jurnal Ekonomi Pertanian Dan Agribisnis. 26 (2) : 71-79.

Supandi, E. D. 2012. Pendekatan Conjoint Analysis untuk mengukur tingkat preferensi mahasiswa terhadap layanan sistem informasi akademik di UIN Yogyakarta. Jurnal fourier. 1(1):1-12.

Syafriadi. 2016. Pengaruh selera dan pendapatan pelanggan terhadap kemampuan beli pelanggan di restoran McDonald's Kuala Namu Sumatera Utara. Jurnal Ilmiah Research Sains. 2(2):1-13.

Tana, E. D., P. R. Kale dan G. E. M. Malelak. 2015. Kandungan lemak, kolestrol, jumlah total bakteri dan rasa bakso babi yang diberi lapisan penutup kitosan, karagenan dan gelatin. Jurnal Nukleus Peternakan. 2(2):186-191.

Wahyuni, S., P. Ari dan H. Wahyu. 2015. Pengaruh tingkat pengalaman berwirausaha, produktivitas dan inovasi Terhadap Pengembangan usaha kulit lumpia. Jurnal Ilmu Administrasi Bisnis. 4(1):263-274.

Wantasen, E., S.J.K Umboh dan E.K.M Endoh. 2019. Exploration of the level of interest and performance of beef attributes in supermarket in Disrict of South Bolaang Mongondow Indonesia. Journal of Business and Economic Development 4 (3): 90-96

Wijayanti, M. 2011. Analisis Preferensi Konsumen Dalam Membeli Daging Sapi di Pasar Tradisonal Kabupaten Karanganyar. Skripsi. Fakultas Pertanian. Universitas Sebelas Maret. Surakarta. 